\title{
The Challenges of Being a Student of Any Public Tertiary Institution in Nigeria of Today
}

\author{
Ige Akindele Matthew (B.Ed, M.Ed, Phd) \\ Deputy Director, Ministry of Education, Akure, Ondo State, Nigeria \\ P.O.Box 2683, Akure, Ondo State, Nigeria \\ Tel: 08-066-305-105Ｅ-mail: dele_divine@yahoo.co.uk
}

Received: Jan. 8, 2012 Accepted: December 20, 2013 Published: February 1, 2014

doi:10.5296/jse.v4i1.1261

URL: http://dx.doi.org/10.5296/jse.v4i1.1261

\begin{abstract}
Tertiary institution serves as an avenue for a child to acquire additional education beyond the primary and secondary education. It can equip a child with additional knowledge, skills, and values, which can enable him/her live comfortably within the society, as well as contribute more to its progress. The desire of many parents is to ensure that their children attend tertiary institution, so as to enjoy the dividends of tertiary education. In this paper, the challenges which the students of public tertiary institutions are facing in Nigeria are examined, such as: inadequate classrooms, ill equipped library and laboratories, incessant closure of institution as a result of students unrest, cultism and strikes, inadequacy and non commitment of some lecturers, just to mention few. Evidences in support of the challenges and their gravities were gathered from literature. To make public tertiary institutions worthwhile for the students and redeem the lost glory of tertiary education in Nigeria, provision of more infrastructural facilities and improvement of the state of those available, monitoring and supervision of the lecturers and enforcement of discipline among erring lecturers, resolving crises in the public tertiary institutions through dialogue, avoiding indiscriminate invitation of law enforcement agents into campuses, avoiding the closure of institutions indefinitely, organising seminars, workshop and conferences for the institutions' administrators, charging moderate fees, generation of fund internally, moral training of children, as well as the provision of needs of children by parents/guardians, are recommended.
\end{abstract}

Keywords: Challenge, Student, Institution, Public, Tertiary institution, Nigeria, Today 


\section{Introduction}

The role of manpower in the development of a country cannot be overemphasized. A developing country such as Nigeria, which is characterised by low literacy level, poor economy, low political, technological and social developments, among other indices (National Bureau of Statistics, 2009; UNESCO Institute of Statistics, 2009; Human Development Report, 2009) needs adequate high-level manpower for her breakthrough. Production of high-level manpower that can guarantee the achievement of these goals can however be achieved through tertiary institutions. In Nigeria, tertiary institutions include the universities, polytechnics, monotechnics, colleges of education, schools of: health technology, schools of nursing, schools of midwifery, and other institutions of higher status than the secondary (Federal Republic of Nigeria, 2004).

Tertiary education is aged in Nigeria. Reports (Adesina, 1977; Fafunwa, 1974) indicate that the first tertiary institution in Nigeria is Yaba Higher College, Lagos, which was established in 1934 and serves as a precursor to the establishment of the University College, Ibadan in 1948 (i.e.as an affiliate of the University of London). This was then based on the need to produce more high-level manpower for the development of the under-developed economy. The attainment of independent status by Nigeria in 1960, also serves as an impetus for expansion of the educational system, particularly at the tertiary level. To this effect, government constituted the Ashby Commission in 1959, to examine the future high-level manpower needs of the country (i.e. from 1960-1980). The implementation of the recommendations of this commission, led to the establishment of Ahmadu Bello University, Zaria; the University of Lagos; and the University of Ife (now Obafemi Awolowo University, Ile Ife) in 1962. During the same year, the University of Ibadan, which was initially an affiliate of the University College, London, was upgraded to full university status, while the University of Nigeria, Nsukka, established in 1960, was formally inaugurated. In 1970, the University of Benin emerged from the Midwest Institute of Technology, which together with the earlier universities, are now the 'first generation universities'.

Propelled by the need to produce additional manpower, to ensure the turnaround of the economy that was then under foreign control, Federal Government established additional seven universities in 1975, which were located at Kano, Jos, Maiduguri, Calabar, Sokoto, Port Harcourt, and Ilorin. Additional universities, which included the state universities also came on board within the decade 1980s and 1990s, as a result of the transition from the military to civil rule in 1979, which placed education in the concurrent legislative list among the three tiers of government (i.e. the federal, state, and local). Of particular interest in the history of tertiary education in Nigeria, is the approval for the establishment of private university in 1999, by the Federal Government, although twenty six of this kind of university were established in 1983 but could not see the light of the day due to the anomalies that were noticed in their operations (National Universities Commission, 1987). Three private universities which include the Babcock University at Ilishan Remo, in Ogun State; the Madonna University at Okija, Rivers State; and Igbinedion University at Okada, Benin City, Edo State were eventually established in 1999. Since then, private universities have been springing up alongside the state universities. As at year 2012, there were forty (40) Federal 
Government owned, thirty nine (39) states governments owned, as well as fifty (50) approved private universities in the country (Teachers Registration Council of Nigeria, 2012) while many are at the stage of being approved by the Federal Government.

Another aspect of tertiary institution development in Nigeria, concerns the monotechnics/polytechnics. According to Adesina (1977), the implementation of the minority report of Elliot's Commission, led to the establishment of Nigerian College of Arts, Science, and Technology in 1952, with branches at Enugu, Ibadan, and Zaria. These were later absorbed by three among the first generation universities (i.e. the University of Ife) (now Obafemi Awolowo University), Ahmadu Bello University, Zaria, and the University of Nigeria, Nsukka (Timilehin, et al, 2010), which later metamorphosed into the polytechnics and monotechnics. Following the creation of additional regions and states in Nigeria, new polytechnics (owned by state governments) emerged. In order to ensure geographical distribution of the facilities for technological education, Federal Government has established federal polytechnic in various parts of the country. As at year 2012, there were twenty (20) federal government's owned, thirty eight (38) states governments' owned, and seventeen (17) approved private polytechnics in Nigeria (TRCN, 2012).

Colleges of education, which form part of tertiary institutions in Nigeria, take their root from the Advanced Teachers' Colleges, the first set of which was established in the wake of independence (i.e. early 1960s), and located at Zaria (Northern region), Owerri (Eastern region), Ibadan (Western region), and Abraka (Mid-West region). The creation of additional states coupled with the increased demand for qualified teachers due to education expansion, led to the establishment of more Teachers' Colleges, which were later renamed as colleges of education. Statistics (TRCN, 2012) also indicate that as at year 2012, there were twenty one (21) federal government's owned, forty four (44) states governments' owned, as well as thirty seven (37) approved private colleges of education in Nigeria.

\section{Purposes of Tertiary Education in Nigeria}

Tertiary education serves as an avenue through which a child can acquire advanced education, beyond the primary and secondary education. It is thus a kind of education aimed at improving the knowledge, skills, and values of a child, as well as enables him/her to live comfortably within the society and contribute meaningfully to its development. The specific purposes of tertiary education include the:

- acquisition, development, and inculcation of proper value orientation for the survival of individual and society;

- development of intellectual capacities of individuals to understand and appreciate their environments;

- acquisition of both physical and intellectual skills which will enable individuals to develop into useful members of the community;

- $\quad$ acquisition of an objective view of the local and external environments (Federal Republic of Nigeria, 2004). 


\section{Challenges of being a student in a public tertiary institution in Nigeria}

Students are formidable inputs in tertiary institutions, apart from the infrastructural facilities and staff. Over the years, the story of students in the public tertiary institutions in Nigeria has been pitiable. Many challenges are faced by students, which are making tertiary education uninteresting, demoralizing, unenjoyable, and frustrating, such as:

\subsection{Inadequate/poor classrooms condition}

Classroom serves as a place where a student can be taught in a school/educational institution. In spite of its role in the teaching-learning process, inadequate classrooms relative to the population of students, characterise many public tertiary institutions in Nigeria (Okebukola, 2002; Monehin, 2003; Saint, Hartnett \& Strassner, 2003; Federal Republic of Nigeria, 2009a; Federal Republic of Nigeria, 2009b; Federal Ministry of Education, 2007; Federal Republic of Nigeria, 2005; National Bureau of Statistics, 2009: Federal Ministry of Education, 2006). Available classrooms in these institutions cannot accommodate many students at a time thus making many students to often run to secure seats to receive lectures. Many students are fond of receiving lectures on their feet, outside classrooms, rather than on their seats. The condition of many classrooms in these institutions, also leaves much to be desired. Many of the classrooms lack the necessary facilities, which can guarantee the comfortability of students while receiving lectures.

\subsection{Ill-equipped Library and Laboratories}

In an educational institution, Library is essential for a student's self study and learning (Fuller, 1985; Popoola, 1989; Federal Republic of Nigeria, 2005). In spite of this, Libraries of many public tertiary institutions in Nigeria, lack adequate and modern books, journals, ICT facilities, and other reference materials (Nwadiani, 1999; Okebukola, 2002), thus making them mere 'consulting centres'. According to Owoeye (2000), Laboratory is essential in the teaching of the sciences and the success of any science subject depends on its provision. Daramola (1985) is also of the opinion that laboratory plays important role in technologically oriented science curriculum and provides student the opportunity to engage in investigation and enquiry. It is however unfortunate that in many public tertiary institutions in Nigeria, equipment in laboratories are inadequate for students while most of those available are obsolete and non-functional (Okebukola, 2002). Due to the state of laboratories in these institutions, many students do graduate without adequate exposure to their usage (Nwadiani, 1999).

\subsection{Inadequate accommodation}

It needs not be over emphasised that a student of tertiary institution needs a place where he/she can rest after each day's activities and prepare for the following day's activities. Bassey (2007) added that the provision of accommodation can encourage a student to participate in the extracurricular activities such as sports, games, club, and social activities, as well as provides security for student, promotes national integration and interaction with other students, as well as enhances moral training of students in campuses. In spite of these benefits, many public tertiary institutions in Nigeria are characterised by inadequate hostels for 
students. The author observed that different kinds of policies are often formulated by authorities, to allocate spaces for the needy students. At times, the first and final year students, the physically challenged, and those involved in sports, are booked for automatic slots. Rather than implementing the policy, majority of the students that suppose to have hostel spaces are often left out due to 'first come, first served' policy that is used to allocate spaces. Majority of students in the public tertiary institutions in Nigeria are staying off campus (i.e. outside the institutions' premises) due to inability to get spaces in the available hostels. Such students are often exploited by the landlords, who are fond of charging exorbitant fee. Due to severe competition for space in the available hostels, there has been accommodation business in the campuses. Many students do buy space (s) at the normal price and resell them at an exorbitant price. A visit to many hostels in the campuses, would buttress that they are like 'refugee camps'. A room that supposes to accommodate four students, usually ends up harbouring twice or more, apart from the 'squatters' who are fond of coming to the hostels to sleep in the night and disappear very early in the morning. Facilities in the hostels are even in most cases inadequate and poorly maintained, to ensure the comfortability of the students.

\subsection{Inadequate transportation facilities}

In Nigeria, many public tertiary institutions operate a 'non-residential policy'. There is thus no adequate provision for transportation of students to and from the campuses daily. The author noticed that in many campuses, few students have personal cars, which can enable them attend lectures promptly. Majority of students, are from less privileged homes and thus have to contend with the boarding commercial vehicle for a fee, so as to move to and from campuses daily. Many students, who cannot afford the cost, often trek to and from the campuses daily, which encourages lateness to classes for lectures, as well as fatigue.

\subsection{High fees}

In Nigeria, public tertiary institutions have been mandated to generate substantial revenue, so as to augment the limited finance flow from Government. This has made the public tertiary institutions to introduce different fees such as examination, medical, caution, graduation, acceptance of admission, among others. Of recent, almost all the public tertiary institutions in Nigeria have increased the fees payable by students, in an attempt to generate more fund for their sustenance, in line with government's directive. This has been causing hardship for students, particularly those from less privileged homes. Many parents/guardians pay through their noses to educate their children/wards in tertiary institutions, which is limiting the access to tertiary institution and encouraging wastage (i.e. dropout and repetition) from the institutions. The issue of fee increase has even been a major factor causing incessant student unrest and closure of tertiary institutions in the country (Ige \& Olowolabi, 2010).

\subsection{Incessant closure of institutions due to students' unrest, cultism, and strikes}

In Nigeria, students' unrest is a tradition in the public tertiary institutions. Several cases of what has now become an albatross in the educational system, had in the past observed in the campuses (Ige and Olowolabi, 2010), many of which even led to the death of students and the destruction of valuable properties within and outside the campuses (Ossai, 2001; Osaigbovo, 
2000; Obadan, 1999; Igodo, 2002; Adewale, 2005; Adelola, 1999). Whether a student likes it or not, he/she has to contend with unrest because it is the weapon of students to fight the institutions' administrators and government over issues such as poor welfares, among others (Ige \& Olowolabi, 2010). It is also the language which government and institutions' administrators understand. The author noticed that although not all the students of public tertiary institutions in Nigeria are disposed to unrest but once the union leaders show interest in it, other students have to join in the struggle. Many students that often show apathy to unrest in campuses are in most cases killed, beaten, and wounded by angry mob. Since a student cannot therefore beat them, he/she has to join them. As a result of incessant student unrest, gates of campuses in Nigeria are often locked thus making their environment to be like graveyards. Academic calendar are also often disrupted and compressed thus hindering effective/quality training of students (Baikie, 2001). At present, a student cannot ascertain when he/she would graduate from any public tertiary institution in Nigeria (Ige and Olowolabi, 2010), no thank to the incessant student unrest that characterise the campuses. Many students that suppose to spend four years to complete a programme, often end up spending twice years. Quite amazing is the fact that students and parents/guardians are at the receiving end of student unrest. Many students are often rusticated and suspended, as well as made to pay through their noses for damages recorded during these unrest.

The issue of cultism is also endemic in the public tertiary institutions in Nigeria. Without mincing words, it is very risky to attend any public tertiary institution in Nigeria. It is like going for a journey of uncertainties. These days, parents need to consult 'seers' to ascertain the fate of their children in the campuses, which are characterised by incessant cult killings. Rather than being 'centres of excellence' or 'ivory towers', many public tertiary institutions in Nigeria, are 'centres of wailing'. Many student who could have been useful to their parents and country, have also lost their lives through cult clashes in the past (Ossai, 2001; Osaigbovo, 2000; Obadan, 1999; Igodo, 2002; Adewale, 2005; Adelola, 1999). Worthy to note is that most of the cult clashes in the campuses centre round the female students. Members of different cult groups often clash over who should be in control of female student (s) in campuses. Most of the female students involved are often raped, brutalized, and murdered by rival cultists. Unfortunately, cultists often proved difficult to be apprehended by institutions' administrators. Even when apprehended, they are usually treated as 'sacred cows' because of 'god fatherism' syndrome and influence of their wealthy parents. In what appears to be a paradox, when notorious cultists who have terminated the lives of innocent students are graduating from tertiary institutions in Nigeria, they are usually presented for graduation with the assertion that they have been found worthy in character and learning in the campuses. Due to incessant cult clashes, there have also been closures of tertiary institutions in Nigeria while attempting to restore peace in the campuses, which has been limiting the time being spent on the training of students and the quality of graduates of the tertiary institutions (Dabaleen, Oni \& Adekola, 2000).

The rate at which strike occur in tertiary institutions in Nigeria is a cause for great concern (Obe, 2003; Nation, 13 ${ }^{\text {th }}$ June, 2011; Onyenoru \& Bankole, 2001; Afolabi, 2003). While some strikes are rooted on disagreement with institutions' administrators over 


\section{Macrothink}

mis-management of fund, most center on the need for increase in salary and generally, improved conditions of service (Onyenoru \& Bankole, 2001; Odewunmi, 2003; Enomah, 2010). While one cannot contest the fact that the demands of staff of public tertiary institutions should be given consideration, strikes suppose to have 'human face' in Nigeria because the interest of students are usually not taken into cognizance as institutions are often closed for weeks/months. Quite amazing is the fact that the Staff of tertiary institutions in Nigeria, under the umbrella of different associations are now rivals. Like children from different mothers who belong to the same father, anything given to or favour done for one has to be done for others to avoid crisis. Anytime government approves wage increase for the academic staff, the non academic counterparts often waste no time to call their members out over the need for government to approve the same for their members. Tertiary institutions in Nigeria have thus been polarized due to demands by the unions. To worsen situation, when closed institutions reopen, academic calendars are often compressed while examinations are hurriedly taken. It is thus disturbing that due to incessant strike in the campuses, international community now finds it difficult to recognize the certificates of tertiary institutions in Nigeria. These days, graduates of tertiary institutions in Nigeria that stepped out of the country for further education have to write and pass 'qualifying tests' due to lack of confidence in their quality.

\subsection{Inadequacy and non-commitment of lecturers}

Inadequacy of teachers has been a bane of educational system in Nigeria in spite of their roles in the dissemination of information to pupils/students and the achievement of schools' objectives (Lassa, 1998; Federal Ministry of Education, 2007; Federal Republic of Nigeria, 2009). Wasagu (2008) reported the extent of lecturers' shortage in tertiary institutions in Nigeria. Data in Table 1 below further shows the student/teacher ratio in federal universities in Nigeria, from 2001-2006, which further confirms the shortage of lecturers in the tertiary institutions. 
Table 1. Student-teacher ratio in federal universities in Nigeria: 2001-2006

\begin{tabular}{|l|l|l|l|l|l|l|}
\hline Disciplines & $\mathbf{2 0 0 1 / 2 0 0 2}$ & $\mathbf{2 0 0 2 / 2 0 0 3}$ & $\mathbf{2 0 0 3 / 2 0 0 4}$ & $\mathbf{2 0 0 4 / 2 0 0 5}$ & $\mathbf{2 0 0 5 / 2 0 0 6}$ & $\begin{array}{l}\text { NUC } \\
\text { Guideline }\end{array}$ \\
\hline Administration & 1 & 33 & 38 & 49 & 38 & 30 \\
\hline Agriculture & 11 & 14 & 13 & 17 & 15 & 15 \\
\hline Arts & 22 & 18 & 25 & 24 & 20 & 30 \\
\hline Education & 24 & 27 & 24 & 30 & 30 & 30 \\
\hline Env. Science & 16 & 18 & 12 & 25 & 20 & 30 \\
\hline Law & 34 & 40 & 36 & 35 & 30 & 15 \\
\hline Medicine & 15 & 13 & 14 & 15 & 12 & 30 \\
\hline Pharmacy & 23 & 14 & 21 & 14 & 12 & 15 \\
\hline Science & 19 & 19 & 23 & 32 & 25 & 15 \\
\hline Social Science & 40 & 30 & 70 & 41 & 40 & 20 \\
\hline Vet. Medicine & 12 & 9 & 14 & 10 & 10 & 30 \\
\hline Total & & & & & & \\
\hline
\end{tabular}

Source: National Bureau of Statistics, Nigeria (2009). Social Statistics in Nigeria

It is unfortunate that these days, many courses in the tertiary institutions are taught by lecturers on contract and sabbatical leave. The situation is not helped by the persistent brain drain in the tertiary institutions (Timilehin, et al, 2010), which has led to the preponderance of 'baby lecturers' in the campuses and having serious negative effects on the production of quality graduates from the institutions. It is even disturbing if one considers the issue of delay in the commencement of lectures in some tertiary institutions. Many lecturers are fond of not going to class to teach students until few weeks to examination. There are those who are fond of compressing lectures for a whole semester into few days or weeks. Production of handouts is a lucrative business and easy way to make money by lecturers and this has replaced serious teaching in classes (Nwadiani, 1999). To worsen the situation, most of the handouts are substandard with exorbitant price tag, which add to the financial burden of students in the campuses. Such handouts are also made compulsory for students to buy and threat of failure awaits anyone who refuses to buy them. There has often been leakage of examinations questions at the back of handouts by lecturers (Ige, 2011) in order to woo the gullible students and advertise their handouts.

\subsection{Harassment of female students}

Harassment of female students has been a contending issue in Nigeria. Some male students, particularly the cultists often rape female counterparts when there is no compromise over love advance (Igodo, 2002). Some male students also hide under campus journalism to expose the secret and background of female students. They are thus fond of cartooning and writing malicious information about them. Some lecturers also lure female students with marks and money so as to cooperate with them over love advance. Threat of failure awaits anyone who refuses to compromise. Anytime there is student unrest in campuses, authorities of institutions usually invite law enforcement agents to help to maintain peace. Rather than 
doing this, some of them do seize the opportunity to rape the female students (Ige \& Olowolabi, 2010).

\section{The way forward}

In view of the challenges which students are facing in public tertiary institutions in Nigeria and the negative effects of these challenges, particularly on the production of ideal graduates, it is imperative for these challenges to be tacked so that the lost glory of tertiary education in Nigeria can be restored. The following measures are thus suggested to achieve this:

\subsection{Adequate funding of public tertiary institutions}

It is not a gainsaying that in spite of the fact that UNESCO has recommended that at least $26 \%$ of the GDP of each country in the world should be spent on education, the case of Nigeria over the years, has shown non-compliance with this policy. Unfortunately, allocation to education sector on which tertiary education depends has been grossly low. Report (Central Bank of Nigeria Statistical Bulletin, 2010) indicates that government's allocation to education from year 2000 to 2009 ranged from $6.07 \%$ to $13 \%$, which is insignificant for meaningful development to be achieved in the sector. There is thus the need for government to allocate more funds to the education sector to meet the established standard.

\subsection{Provision of more Infrastructural facilities and improvement of the state of those available}

In view of infrastructural facilities inadequacy and decay in public tertiary institutions in Nigeria and the effects of this on the teaching-learning process in the institutions, there is need for Government to provide more infrastructural facilities for the tertiary institutions. Available infrastructures should also be repaired. Modern and adequate books and equipment should be procured and stored in the libraries while the laboratories should be equipped with adequate and modern equipment. There should also be provision of more accommodation for students. The' 'Build on Transfer' policy of government which is meant to encourage the private sector to invest in the construction of hostels and provision of accommodation for students of tertiary institutions should be effectively implemented in view of the growing need of students for accommodation in the campuses. Transportation of students especially in the non residential institutions should be given attention. More vehicles should be procured while available ones should be maintained to transport students on daily basis.

\subsection{Monitoring of lecturers and enforcement of discipline of erring lecturers}

Each tertiary institution should always monitor the lecturers to ensure that they commence lectures very early. Any case of dereliction of duties by any lecturer should be met with appropriate disciplinary action. There should however not be sacred cow in this regard. Selling of handouts by lecturers should be banned in the campuses. Rather, lecturers should be encouraged to produce quality textbooks which must be sold to students at affordable prices. Buying of textbooks should however not be made compulsory by lecturers. Head of 
departments in the tertiary institutions should monitor the lecturers and ensure strict compliance with this policy.

\subsection{Resolving crises through dialogue}

Tertiary institution harbors students and staff from diverse background and of different characteristics. There is therefore bound to be conflict in their interaction. Tertiary institution administrators should however embrace dialogue in resolving student and staff crises.

\subsection{Avoiding indiscriminate invitation of Law enforcement agents into campus}

Law enforcement agents should not be invited into campuses indiscriminately. While it has become inevitable to do so, they should be properly advised not to use ammunition against students and also behave in decent manner. Prevention, as the saying goes, is better than cure, institutions' administrators should always guide against any action that may trigger unrest in campus. Students welfares should however be given attention.

\subsection{Avoiding the closure of institution indefinitely}

Institutions should also not be closed indefinitely. Rather, institutions' administrators should ensure that when such institutions are re-opened, the normal academic schedule of lectures is still followed i.e. there should not be compression of academic calendar.

\subsection{Organising seminars, workshop and conferences for the Institutions’ Administrators}

Each institution's administrators should be made to attend students' management seminars and workshops regularly which will go a long way in effecting adequate leadership standard in such institution.

\subsection{Charging moderate fees and generation of fund internally}

Institutions' administrators are enjoined to charge moderate fees which can be afforded by majority of the students. Government should however continue to moderate the fees payable by tertiary institutions in Nigeria and should provide more scholarship opportunities for the brilliant students so as to alleviate the hardship being faced by parents in the efforts to educate their children. In view of the dire need of tertiary institutions in Nigeria for adequate funds more so that government has over the years not been capable of providing adequate funds for tertiary institutions needs, each institution's administrators should explore ways of generating fund internally which can be through promotion of consultancy services; linkage with philanthropic institutions and individuals among others so as to go a long way in improving their financial base.

\subsection{Moral training of children and provision of the needs of children by parents}

Charity as the saying goes begins at home. There is need for proper moral training of children by their parents. If this is ensured, cases of cultism, examination malpractice, raping among others would be a thing of the past. Parents also need to monitor the activities of their children in tertiary institutions through regular visitations and discussion with lecturers and administrators. They should also provide the needs of their children so as to be focused on their studies in the institutions. 


\section{Summary and Conclusion}

Tertiary education is a unique part of education, where a child can acquire additional education beyond the lower levels (i.e. the primary and secondary). Unfortunately, students of public tertiary institutions in Nigeria are facing many challenges which are undermining the dividends accruable through it. Attempt had been made in this paper to discuss these challenges which students face in public tertiary institutions in Nigeria, which are making tertiary education less uninteresting, unenjoyable, frustrating, as well as demoralising to students. How to tackle these challenges were also discussed with a view that if the stakeholders in education such as parents, government, institutions' administrators rise up to the task of combating them, the lost glory of tertiary education in Nigeria would be redeemed.

\section{References}

Adelola, I.O.A. (1999, September $2^{\text {nd }}-3^{\text {rd }}$ ). Combating cultism in Ondo State University, Ado Ekiti through Socio-Political Approach. A paper presented at a two day conference on combating Cultism in Nigerian Tertiary Institutions organized by Ondo State University, Ado Ekiti.

Adesina, S. (1977). Planning and educational development in Nigeria. Lagos, Nigeria: Educational Industries Limited.

Adewale, R. (2005). Violence in the citadel: The menace of secret cults in Nigerian Universities. Nordic Journal of African Studies, 14(1), 79-98

Adiukwu, M.U. (2009, 24 ${ }^{\text {th }}-28^{\text {th }}$ May). Nigeria Country’s Report in Post-Basic S \& T Education. Paper presented at the International Council of Associations for Science Education (ICASE) at Abuja, Nigeria

Afolabi, S.O. (2003, 31 ${ }^{\text {st }}$ October). ASUU on one Hand: SSANU and NASU on the other Hand: The Acrimony between these Unions. Paper presented at the National University Stakeholder Consultative forum organized by Federal Ministry of Education.

Baikie, A. (2001, 26 $6^{\text {th }}-30^{\text {th }}$ November). Management of Authority and Student Relationship under University's Autonomy. Paper presented at the $3^{\text {rd }}$ National Training Programme for Senior University Managers (NAPTSUMA III).

Bassey, U. (2007). Hostel Accommodation in Tertiary educational institutions in Nigeria: To be or not to be?

Central bank of Nigeria. (2010). Statistical bulletin. Abuja, Nigeria: Federal Government Press.

Dabaleen, A., \& Adekola, A.O. (2000). Labour market prospects for university graduates in Nigeria. Background Study Conducted to inform the Design of the Nigerian University System's Innovation Project. Washington D.C: World Bank.

Daramola, S.O. (1985). The role of science laboratory in a technologically oriented science 
Curriculum. Ilorin Journal of Education, 5, 48-49

Enomah. S. (2010). Joseph Omoregbe's Philosophy of Civil Disobedience and the Imperativeness of the 2009 ASUU Strike: Implications for a sustainable Higher Education in Nigeria. Continental Journal of Arts and Humanities, 2, 32-37.

Fafunwa, A.B. (1974). History of education in Nigeria. U.K; George Allen \& Urwin Limited.

Federal Ministry of Education. (2006). Education Sector Analysis. Abuja, Nigeria: Federal Government Press

Federal Ministry of Education. (2007). Statistics of education in Nigeria: 1999-2005.Abuja, Nigeria: Federal Government Press

Federal Ministry of Education. (2007). Statistics of Education in Nigeria: 1999-2005. Abuja, Nigeria: Federal Government Press.

Federal Republic of Nigeria. (2004). National Policy on Education (Revised) Abuja, Nigeria: Federal Government Press.

Federal Republic of Nigeria. (2005).Nigeria Education Sector Diagnosis. Abuja, Nigeria: Federal Government Press.

Federal Republic of Nigeria. (2009). The State of Education in Nigeria. Abuja, Nigeria: Federal Government Press

Federal Republic of Nigeria. (2009a). Annual Abstract of Statistics. Abuja, Nigeria: Federal Government Press.

Federal Republic of Nigeria. (2009b).The state of education in Nigeria. Abuja, Nigeria: Federal Government Press

Fuller, B. (1985). Raising school quality in developing countries: What investment to boost learning. World Bank Discussion Paper. Washington, DC, USA

Ige, A.M. (2011). Issues in sandwich approach for training and improving teachers in Nigeria. Journal of Educational Research and Development, 5(3), 16-23

Ige, A.M., \& Olowolabi, S. (2010). Student Unrest in Tertiary Institutions in Nigeria Cause and remedies. Journal of Educational Research and Development, 4(3), 137-146.

Igodo, C. (2002). Campaign against cultism and drug addiction among youths in Nigeria. Calabar, Nigeria. Centre for General African Studies, Research and Documentation.

Lassa, P. (1998).Teacher Production: A focus on Nigeria. In UNESCO (Ed).The state of Education in Nigeria. Lagos, Nigeria: NESCO Regional Office.

Monehin. O.B. (2003, $31^{\text {st }}$ March). The University and the Development of Nigeria Society. Paper delivered at the universities' stakeholders' forum at Abuja, Nigeria

National Bureau of Statistics. (2009). Social Statistics in Nigeria. Abuja, Nigeria: Federal Government Press 


\section{Macrothink}

Journal of Studies in Education

ISSN 2162-6952

2014, Vol. 4, No. 1

National Universities Commission. (1987). 25 years of centralized universities education in Nigeria. Lagos, Nigeria: Federal Government Press

Nwadiani, M. (1999). Dystrophies in higher education: The Nigerian experience. Higher Education Review, 31(3), 17-26.

Obadan, C.E. (1999, September $2^{\text {nd }}-3^{\text {rd }}$ ). Combating cultism in Ondo State University, Ado Ekiti through Law enforcement: An Institutional Approach. Paper presented at a two day conference on combating cultism in Nigerian Tertiary Institutions, organized by Ondo State University, Ado Ekiti, Nigeria

Obe. (2003, $31^{\text {st }}$ March). The University and the Development of Nigerian Society. Paper presented at the Universities' Stakeholders forum at Abuja, Nigeria

Odewumi, S.G. (2003, 31 ${ }^{\text {st }}$ October). Towards a more Productive University Education in Nigeria: Some Strike Avoidable Strategies. Paper presented at the national university Stakeholders forum, organized by Federal Ministry of Education, Nigeria

Okebukola, P.A.O. (2002). The state of university education in Nigeria. Abuja, Nigeria: National Universities Commission

Onyeonoru, I., \& Bankole, A. (2001, $3^{\text {rd }}-7^{\text {th }}$ July). Conflict Management and University Sustainability: The Role of Administrators and Campus Unions. Paper presented at the $12^{\text {th }}$ General Assembly of Social Sciences Academy of Nigeria, held at Abuja, Nigeria.

Osaigbovo, J.A. (2000). Cultism and Administration of Higher Education in Nigeria. Seminar for PhD student, Delta State University, Abraka, Nigeria.

Ossai, A.G. (2001). Cultism and Management of Higher Education. Seminar paper presented at the Faculty of Education, Delta State University, Abraka.

Owoeye, J.S. (2000). The Effect of Integration of Location, Facilities and Class Size on Academic Achievement of Secondary School Students in Ekiti State. Unpublished PhD Thesis, University of Ibadan, Nigeria.

Popoola, T.A. (1989). Investigation between instructional resources and learning outcomes. npublished M.ED Thesis, University of Ibadan.

Saint, W., Hartnett, T.A., \& Strassner, E. (2003). Higher education in Nigeria: A status report. Higher Education Policy, 16, 259-281 http://dx.doi.org/10.1057/palgrave.hep.8300021

Teachers Registration Council of Nigeria (2012). Statistical Digest of Teachers in Nigeria (2011/2012), 7. Abuja, Nigeria, Teachers Registration Council of Nigeria

The Nation. (2011, $13^{\text {th }}$ June, p.7)

Timilehin, E.H., Esohe, K.P., Osalusi, F.M., \& Babatope, A. (2010). Towards redressing the Brain drain syndrome in Nigerian universities. American-Eurasian Journal of Scientific Research, 5(3), 156-160

UNESCO Institute of Statistics. (2007). Global Education Database. 
United Nations. (2009). Human Development Report

Wasagu, M.A. (2008, 23 ${ }^{\text {rd }}$ August). Reform Agenda of the Nigerian Education Sector: Providing Solution or Evading the Real Problem? Science Teachers Association Memorial Lecture Series No 20, presented at Minna, Nigeria 